had practical training in engineering totalling 104 weeks. Candidates will be required to write $a_{0}$ thesis of 2,000-4,000 words on a subject approved by the Ministry of Education and may be required to sit for a short examination on the basic principles of engineering and to appear for an interview before an examining body. Further details can be obtained from the Ministry of Education.

\section{Oversea Service Division, Colonial Office}

THe following appointments have recently been made in the Oversea Service Division, Colonial Office : J. Bowden (assistant director of agriculture (research), Ghana), senior entomologist, Uganda ; C. E. Johnson (assistant director of agriculture, Northern Rhodesia), deputy director of agriculture, Northern Rhodesia; A. G. K. Will (field officer, agriculture, Uganda), senior field officer, agriculture, Uganda; R. W. Aleong (assistant government chemist, Trinidad), deputy government chemist, Trinidad; E. G. N. Greaves (government chemist, Trinidad), chemist, Medical Department, Hong Kong; A. E. Kerr (deputy government chemist, Trinidad), government chemist, Trinidad; L. A. M. Lloyd (chief instructor, Kingston Technical School, Jamaica), vice-principal, Kingston Technical School, Jamaica; R. W. J. Keay (research officer, Federation of Nigeria), principal research officer, Department of Forest Research, Federation of Nigeria; W. E. M. Logan (deputy chief conservator of forests, Uganda), chief conservator of forests, Uganda; J. A. Channon (meteorologist, East African Meteorological Department), senior meteorologist, East African Meteorological Department; J. E. Richardson (assistant superintendent of Crown Lands and Surveys, Hong Kong), superintendent of Crown Lands and Surveys, Hong Kong; J. R. Knowles (senior veterinary officer, Northern Nigeria), principal veterinary officer, Northern Nigeria; B. E. B. Fagg (surveyor of antiquities, Federation of Nigeria), director, Department of Antiquities, Federation of Nigeria; W. G. Addison, agricultural officer, Western Nigeria ; R. F. Allbrook, soil survey officer, Western Nigeria; K. C. Baxter, agricultural engineer, Northern Nigeria; D. B. Roberts, irrigation engineer, Agricultural Department, Northern Nigeria; J. C. M. Trail, livestock improvement officer, Uganda ; R. Webster, soil chemist, Northern Rhodesia; W. D. Carslake, assistant conservator of forests, Sierra Leone; E. W. Chapman, assistant conservator of forests, Kenya ; J. M. MacKenzie, assistant conservator of forests, Somaliland; T. S. Wormald, assistant conservator of forests, Kenys ; F. J. Matheson, geologist, Kenya.

\section{The Night Sky in January}

FUIL moon occurs on Jan. 5d. 20h. 09m. U.T., and new moon on Jan. 19d. 22h. $08 \mathrm{~m}$. The following conjunctions with the Moon take place: Jan. 13d. $05 \mathrm{~m}$., Jupiter $2^{\circ}$ N. ; Jan. 16d. 15m., Mars $3^{\circ} \mathrm{S}$. ; Jan. 16d. 23h., Saturn $2^{\circ} \mathrm{S}$. In addition to these conjunctions with the Moon, Mars is in conjunction with Antares on Jan. 4d. 05h., Mars being $4.7^{\circ} \mathrm{N}$., and Mars with Saturn on Jan. 23d. 10h., Mars being $1.5^{\circ} \mathrm{S}$. Mercury is a morning star, rising rather more than an hour before the Sun, but conditions for observation are unfavourable. Venus is a brilliant object low in the south-west after sunset; it sets at 19h. $05 \mathrm{~m}$. and $18 \mathrm{~h} .55 \mathrm{~m}$. on January 1 and 15 , respectively. Its stellar magnitude is about -4 ; the visible portion of the apparent disk is 0.192 on
January 1 and $0 \cdot 067$ on January 15 . Venus is too close to the Sun for observation at the end of the month, inferior conjunction being on January 28 . Mars rises at $5 \mathrm{~h}$. $35 \mathrm{~m}$. at the beginning of the month and at $5 \mathrm{~h} .20 \mathrm{~m}$. on January 31 ; it is visible in the south-east before sunrise. Jupiter rises at $1 \mathrm{~h}$. $55 \mathrm{~m}$., lh. $10 \mathrm{~m}$. and $0 \mathrm{~h} .15 \mathrm{~m}$. on January 1,15 and 31 respectively ; it is east of Spica. 'The stellar magritude of Jupiter is $-1 \cdot 5$, its distance from the Earth on January 15 being 510 million miles. Saturn rises at $6 \mathrm{~h} .30 \mathrm{~m} ., 5 \mathrm{~h} .45 \mathrm{~m}$. and $4 \mathrm{~h} .50 \mathrm{~m}$. at the beginning, middle and end of the month, respectively ; it is near $\theta$ Ophiuchi, and may be visible low in the south-east before sunrise. It has a stellar magnitude of +0.8 and a distance of 1,010 million miles from the Earth on January 15 . Occultations of stars brighter than magnitude 6 are as follows, observations being made at Greenwich; Jan. 7d. 22h. 32.6m., $x$ Cnc. $(R)$; Jan. 10d. 06h. $45 \cdot 1$ m., 69 Leo. $(R)$; Jan. 30d. 22h. 45.5 m., 97 Tau. $(D) . \quad R$ and $D$ refer to reappearance and disappearance, respectively. The Quadrantid meteors are active on January 3 , but conditions are unfavourable. The Earth is at Peribelion on January 3, its distance from the Sun being 91.4 million miles.

\section{Announcements}

ThE Kalinga Prize for the popularization of science, offered annually by the United Nations Educational, Scientific and Cultural Organization, has been awarded for 1957 to Earl Russell (Bertrand Russell).

A symposium on "The Chemistry of Plastics" will be held on February 14 and 15 at the Bradford Institute of Technology, Great Horton Road, Bradford 1. Further information can be obtained from Dr. W. R. Moore, Chemistry Department, Technical College, Bradford.

A general meeting of the Association of Applied Biologists will be held in the Large Chemistry Lecture Theatre, Imperial College, Imperial Institute Road, South Kensington, London, S.W.7, on January 10. After the formal business of the meeting, there will be a symposium on "The Use of Insecticides for the Control of Virus Diseases". Further information can be obtained from Dr. L. Broadbent, Rothamsted Experimental Station, Harpenden, Herts.

The Medical Research Council Tropical Metabolism Research Unit, University College of the West Indies, Mona, St. Andrew, Jamaica, has a limited stock of dried lanterns from fireflies (Photinus pallens), which may be used for measuring adenosine triphosphate by methods described by McElroy et al. (McElroy, W. D., and Strehler, B. L., Arch. Biochem., 22, 420; 1949. Green, A. A., and McElroy, W. D., Biochim. Biophys. Acta, 20, 170 ; 1956). The Tropical Metabolism Research Unit will supply them at a price of $£ 210 s$. a hundred, which covers the expense of collection and includes air-mail postage, to research workers who apply to the address above.

Errata. In the communication entitled "Solution of Mineral Phosphates by Soil Bacteria", by Joan I. Sperber, in Nature of November 9, p. 994, par. 3, line 3 , for "hydroxyapatite $(220 \mu \mathrm{mgm}$. P/ml.)" read "hydoxyapatite $(220 \mu \mathrm{gm} . \mathrm{P} / \mathrm{ml}$.$) "; similarly, in$ par. 4, lines 4 and 5 , in the phrase " 1,200 umgm. lactic acid was sufficient to bring $220 \mu \mathrm{mgm}$. phosphorus into solution", the quantities should be $1,200 \mu \mathrm{gm}$. and $220 \mu \mathrm{gm}$., respectively. 